\section{Contributors}

Niall Cameron is an appraisal director for NHS Scotland. His new eau de cologne, Hint of Sulphur, is available at better postgraduate outlets soon. niall.cameron@nes.scot.nhs.uk

Mike Fitzpatrick's thoughts are further explained at www.spiked-online.com fitz@easynet.co.uk

Dougal Jeffries practises in the Scilly Isles. He boats. dougal6@gmail.com

Michael Lasserson plays the double bass in the European Doctors Orchestera. mlasserson@hotmail.com

Murray Lough is also NES and a member of the BJGP Editorial Board. $\mathrm{He}$ is a man of Gullane, a Russophile, and an admirer of lighthouses. murraylough@yahoo.co.uk

Saul Miller practises in

Northumberland.

saulmiller@me.com

Lesley Morrison practises in Peebles in the Scottish Borders. Lesley.Morrison@borders.scot.nhs.uk

Jane Roberts is a senior clinical lecturer in general practice, University of Sunderland. jane.roberts@sunderland.ac.uk

David Stevenson is a Glasgow graduate with a famous nickname available from the Editorial Office for a small fee.

dstevenson2@nhs.net

Graham Watt is a professor of general practice at Glasgow. A long time ago he was Julian Tudor Hart's registrar in South Wales.

g.watt@clinmed.gla.ac.uk

James Willis commuted to schoo on the Queen Mary, the first one, not the floating condominium that presently bares this name. jarwillis@gmail.com

The Tips for Trainees series is edited by Matthew Burkes a GP from Chichester.

mattburkes@doctors.org.uk His co-authors this month are Kate $\mathbf{H}$ Bunyan a clinical fellow in emergency medicine with an interest in pre-hospital and maritime medicine and Ben Atkinson.

\title{
In for a penny, in for a pound
}

Money talks. There is no getting away from it. Everyone is trying to earn a crust. Opportunities are hard to pass by. Principles are all very well but they don't keep your feet warm when the snow comes.

Of course, some really do stick to their principles even when doing so risks the security of their own money supply. What of them? The cynics would say such people are already rich - they can afford it. And truthfully, those that do and aren't already rich, they are exalted but rare. True paragons of virtue exist but I struggle to think of those I know.

The great majority of us muddle through. We try to be good but are suitably hazy about those principles at times, sinking into moral relativity, seeing everything in shades of grey when needs must.

And so at this time of year we find ourselves sifting through the records of patients we have sifted through annually at this time before. Another 12 months and their blood pressure is still not low enough, they are not on that beta-blocker or ACE inhibitor or whatever it is that our contract targets dictate. Can we validly except them? Should we review the original diagnosis - perhaps it was the wrong label to apply anyway?

Did we feel proud to have achieved so many targets last year? Will we this year, if we repeat the feat again? No, not really. It was more of a sense of relief that we had not lost income. A sense of relief that we had passed scrutiny by the payers.

The money tied to these targets was once meant to have funded investment in staff and buildings and whatever else might improve the quality of the services we provide. But tying the funds to changing targets created inherent uncertainty: not the conditions for safe investment. In setting us all to chase these targets, an opportunity was lost.

From April, our practice contract has been renewed for a period that should see out our PCT. We have been offered, in a take-it-or-leave-it form of negotiation, less money again. Though we have accepted, our black-and-white view of our PCT remains unchanged.
Those responsible for the decisions are all too busy jockeying for positions in the new NHS structure to care. No doubt their applications will look all the better for the balanced books they will leave behind. In this transaction we were a casualty of their need to earn a crust.

There are countless more examples of finance driving impure behaviour in the local NHS. GP Commissioning groups are blossoming at such a fast rate that high moral principles cannot be to blame. It matters to be involved because we are being paid to. But do I feel any sense of ownership, of joy at the possibility of finally getting control over the way the NHS is run? None. Not a gleam. One county-wide organisation is being replaced by another. I feel no closer to the heart of things. Indeed, talk of federating with other practices has appeared in relation to GP Commissioning and I hear it not as a principled idea of how to share skills and resources but rather as an insidious ceding of control.

Melodramatic this may sound but I see no virtue in a system that allows competition on the basis of price alone. Now that the government has unleashed this daemon, quality is no longer king. There may have been perverse incentives while it was, but I fear what comes next more than what has been.

Money talks. Who can resist?

DOI: 10.3399/bjgp11X561492 